\title{
Treatment of intractable chronic cluster headache by occipital nerve stimulation: a cohort of 51 patients
}

\author{
${ }^{1}$ Sarah Miller MBBS, MRCP ${ }^{2}$ Laurence Watkins FRCS, PhD and ${ }^{1}$ Manjit Matharu \\ FRCP, PhD \\ ${ }^{1}$ Headache Group, Institute of Neurology and The National Hospital for Neurology and \\ Neurosurgery, Queen Square, London, UK \\ ${ }^{2}$ Department of Neurosurgery, Institute of Neurology and The National Hospital for \\ Neurology and Neurosurgery, Queen Square, London, UK
}

Prepared For: European Journal of Neurology

Abstract: 252

Introduction: 296

Methods: 581

Results: 933

Discussion: 1294

Total word count (including abstract, introduction, body, discussion and references): 3356

Total pages: 32

Tables: 6

Figures: 1

References: 25

Supplementary Data ONLINE ONLY: Tables-3

\section{Corresponding Author:}

Dr Manjit Matharu

Senior Lecturer and Honorary Consultant Neurologist

Headache Group, Institute of Neurology and The National Hospital for Neurology and Neurosurgery, Queen Square, London WC1N 3BG

Email:m.matharu@uclmail.net

Tel: +447595900535

Fax: +44 7092120797 


\section{Running Title:}

ONS for $\mathrm{CCH}$

\section{Key Words:}

Cluster headache, Headache, Neurostimulation, Occipital Nerve Stimulation

\section{Author contributions:}

SM recruitment of subjects, analysis and interpretation of data, drafting and revision of manuscript.

LW performed surgery and manuscript revision

MSM study concept, recruitment of subjects, interpretation of data and manuscript revision.

\section{Disclosures:}

SM has received educational and travel grants from St Jude Medical and Medtronic.

LW has served on advisory boards for St Jude Medical and Medtronic.

MSM serves on the advisory board for Allergan, St Jude Medical and Medtronic and has received payment for the development of educational presentations from Allergan, St Jude Medical, Medtronic and electroCore.

\section{Study funding:}

This study was supported by an investigator-initiated research grant by Medtronic Inc (Dr Matharu). The funders of this study had no role in the design or conduct of this study; in the collection, management, analysis or interpretation of the data; or in the preparation, review or approval of the manuscript.

\section{Acknowledgements:}

We would like to thank our Headache Specialist Nurses, especially Mrs Susie Lagrata, for their help with completion of the clinical database and management of the patients. We also thank the patients and their families for their help with this project. 


\section{ABSTRACT}

Chronic cluster headache is a rare, highly disabling primary headache condition. When medically intractable, occipital nerve stimulation can offer effective treatment. Open-label series have provided data on small cohorts only. We analyzed 51 subjects to evaluate the long-term outcomes of highly intractable chronic cluster headache with occipital nerve stimulation. Patients with intractable chronic cluster headache were implanted with occipital nerve stimulators during the period 2007-2014. Primary endpoint was improvement in daily attack frequency. Secondary endpoints included attack severity, attack duration, quality of life measures, headache disability scores and adverse events. We studied 51 patients (35 male): mean age at implant 47.78 years (range 31-70) and mean follow-up 39.17 months (range 2-81 months). Nineteen patients had other chronic headache types in addition in chronic cluster headache. At final follow-up, there was a $46.1 \%$ improvement in attack frequency $(\mathrm{p}<0001)$ across all patients, $49.5 \%(\mathrm{p}<0.001)$ in those with cluster headache alone and $40.3 \%(\mathrm{p}=0.036)$ in those with multiple phenotypes. There were no significant differences in response of those with or without multiple headache types. The overall response rate (defined as at least a $50 \%$ improvement in attack frequency) was $52.9 \%$. Significant reductions were also seen in attack duration and severity. Improvements were noted in headache disability scores and quality of life measures. Triptan use of responders dropped by $62.56 \%$ resulting in significant cost savings. Adverse event rates were highly favorable. Occipital nerve stimulation appears to be a safe and efficacious treatment for highly intractable chronic cluster headache even after a mean of over three-years follow-up. 


\section{INTRODUCTION}

Cluster headache is a primary headache disorder characterized by bouts during which patients experience multiple attacks of severe unilateral pain associated with cranial autonomic features [7]. When attacks occur for over one year with remissions lasting less than one month then the condition is said to be chronic. Cluster headache has a prevalence of around $0.1 \%$ [20] with $10-15 \%$ of this group suffering chronic cluster headaches $(\mathrm{CCH})$ [8].

Cluster headache can be successfully treated with a range of oral and injectable medications. However, a proportion of $\mathrm{CCH}$ patients are intractable to all available medications. Although a unifying definition of refractory $\mathrm{CCH}$ is still awaited, guidelines from Goadsby et al. suggest that patients meet diagnostic criteria for $\mathrm{CCH}$ and have failed at least four classes of drugs from verapamil, lithium, methysergide melatonin, topiramate or gabapentin, with at least two from the first three agents [6]. More recently, the European Headache Federation defined refractory $\mathrm{CCH}$ as patients meeting ICHD-3beta criteria who continue to suffer from at least three severe attacks a week despite adequate trials of at least three of the following: verapamil, lithium, oral or IV steroids, greater occipital nerve blockade, topiramate, methysergide, ergots, civamide or long-acting triptans [16]. Due to the highly disabling nature of intractable $\mathrm{CCH}$, destructive surgical approaches to treatment have been investigated with disappointing results. Neurostimulation techniques involving peripheral and central targets have now emerged as promising therapies. Peripheral stimulation of the occipital nerve has been investigated as a potentially useful treatment for chronic migraine $(\mathrm{CM})$ in a limited number of randomized control studies $[11 ; 21 ; 24]$ and for $\mathrm{CCH}$ in a number of small open label series $[1 ; 2 ; 4 ; 5 ; 12 ; 14 ; 19 ; 22]$.

We report the long-term follow-up of 51 intractable $\mathrm{CCH}$ patients treated with occipital nerve stimulation (ONS). 


\section{METHODS}

\section{Patients}

Patients with intractable $\mathrm{CCH}$ seen in the headache clinic at the National Hospital for Neurology and Neurosurgery, Queen Square, London, UK were offered ONS. Patients were reviewed and operated on by a single multidisciplinary headache team, consisting of headache specialists, neurosurgeons and headache specialist nurses with access to psychology and psychiatry services. Implants took place over a period from October 2007 to June 2014. Follow-up visits occurred every three months for the first year and then every six to twelve months thereafter. All patients fulfilled the International Classification of Headache Disorders (ICHD) $2^{\text {nd }}$ edition and revised ICHD-3beta diagnostic criteria for $\mathrm{CCH}$ as well as also the proposed criteria for intractable $\mathrm{CCH}[6 ; 8]$. Under the supervision of our institution's Clinical Effectiveness Supervisory Committee with arrangements for clinical governance, consent and audit, we offered ONS to patients with intractable $\mathrm{CCH}$. The procedure was provided on the basis of a "humanitarian intervention". In addition, ethics board approval for data collection and publication was granted by Northwick Park Hospital Research Ethics Committee, Hampstead, London, UK.

\section{Surgical Procedure}

ONS systems were implanted as described elsewhere [9]. Bilateral octad electrodes were placed in all patients (Table 1). Medtronic systems were implanted in 48 (94.1\%) and St Jude Medical systems in 3 (5.9\%). Patients did not undergo trial stimulation. Implantable pulse generators (IPG) were placed in subclavicular or abdominal pockets dependent on patient preference.

Pg. 5 
At initial programming, frequency was set at $60 \mathrm{~Hz}$ with a pulse width of $240 \mu$ s. Polarity of the electrodes was adjusted during follow up visits to ensure comfortable bilateral paranesthesia in the occipital region. Patients used continuous stimulation but were able to adjust the amplitude. Medications were changed at the discretion of the headache specialist.

\section{Data Collection}

Data were collected prospectively and entered onto a clinical database (Microsoft Excel, Microsoft Corporation, Redmond, WA, USA). Data including demographics, diagnosis, attack frequency, previous and current treatments, and adverse events were recorded. Patients prospectively completed headache diaries recording the frequency, severity on a verbal rating scale (VRS; $0=$ no pain to $10=$ extreme pain) and duration of cluster headache attacks for one month prior to implant and two weeks prior to each follow-up visit. Diaries were used to calculate mean daily attack frequency, severity and duration over these periods of time. Where multiple headache types were present, patients completed separate diaries for each.

Migraine Disability Assessment Scores (MIDAS) and Headache Impact Test 6 Scores (HIT6) were recorded pre- and post-ONS to monitor headache related disability. Although MIDAS has not been validated for its use in $\mathrm{CCH}$, it has been used extensively in the assessment of other primary headache disorders including cluster headache [22]. Euro-QoL, Short Form 36 Questionnaires (SF36), Beck Depression Inventory II (BDI-II), Hospital Anxiety (HAD-A) and Hospital Depression (HAD-D) Scores were used to monitor quality of life and mental state.

Primary outcome measure was improvement in mean daily attack frequency at final followup compared to baseline. Response was defined as a $50 \%$ or more reduction in mean daily 
attack frequency. Secondary outcome measures included attack severity, attack duration, headache-related disability scores, affective measures and quality of life scores.

\section{Statistics}

All statistical analyses were conducted using IBM SPSS Statistics version 22 (IBM Corp. Int.). A last observation carried forward technique was used in the case of missing data. Descriptive statistics were summarized as appropriate. Data is presented as mean $\pm \mathrm{SD}$, range and frequencies. Paired and independent t-tests were used to compare treatment effect as appropriate. All statistical tests were two-sided with a significance level of $95 \%$.

\section{RESULTS}

\section{Patient demographics}

Thirty-five men and 16 women with a mean age of 47.78 years (range $31-70$ years) were implanted. Mean duration of chronic cluster headache at implantation was 7.88 years (range 2-43 years). The mean number of medications prior to implant was $12.57 \pm 2.91$ (range 7-21). (Supplementary Table 1). Nineteen patients (37.3\%) had other chronic headaches in addition to $\mathrm{CCH}$ : 13 had $\mathrm{CCH}$ and $\mathrm{CM}$, three had $\mathrm{CCH}$ and short-lasting unilateral neuralgiform headache attacks (SUNHA) and three $\mathrm{CCH}, \mathrm{CM}$ and SUNHA. All kept separate diaries for each phenotype throughout follow-up. Table 2 provides demographic data for the cohort.

\section{Whole Cohort}

Mean follow-up time was 39.17 months (range 2-81). At follow-up four patients had had their implants removed, 3 for lack of efficacy and one for intractable neck pain secondary to lead tethering. Figure 1a shows the percentage improvement in daily attack frequency over 
the follow-up period. At final follow-up, 52.9\% $(\mathrm{n}=27)$ of patients achieved at least a 50\% reduction in daily attack frequency (i.e. were classed as responders). Mean daily attack frequency fell by $46.1 \%( \pm 43.7)(\mathrm{p}<0.001)$. Over the course of follow-up, $47.1 \%(\mathrm{n}=24)$ patients reported over six months of continuous pain-freedom. The mean duration of pain freedom was 16.25 months (range 6-48). Significant reductions were also seen in attack intensity (26.4\%) and duration (43.3\%) (Table 3). Across the cohort, significant improvements were observed in MIDAS (-34.92), HIT-6 (-7.05), HAD-A (-2.04), HAD-D (2.82) and BDI-II (-4.77) scales. Quality of life scores showed improvements but only that in SF-36 mental composite score was significant (Table 4). Non-responders to ONS failed to show any improvement in any headache disability, affect or quality of life scores. Responders showed significant improvements in all headache disability scores and affective scores as well as SF-36 mental composite score (Supplementary Table 2). Patient estimate of overall $\mathrm{CCH}$ improvement was $53.7 \%( \pm 38.60)$. Differences in outcomes of responders and non-responders are shown in Supplementary Table 3.

\section{Chronic cluster headache alone}

In the 32 patients with $\mathrm{CCH}$ alone, mean follow-up time was 42.59 months (range 2-81). Figure $1 \mathrm{~b}$ shows the change in daily attack frequency over follow-up. A $50 \%$ response was observed in $53.1 \%(\mathrm{n}=17)$ patients. Mean daily attack frequency reduced by $49.5 \%( \pm 43.84)$ $(\mathrm{p}<0.001)$. Significant improvements were also seen in daily attack severity $(25.0 \%)$ and duration (43.2\%) (Table 3). Significant change was seen in MIDAS (-47.66), HIT-6 (-7.62), HAD-A (-2.03), HAD-D (-2.81) and BDI-II (-6.43). However, no significant improvements were observed in any quality of life measures (Table 4).

\section{Multiple phenotypes including $\mathrm{CCH}$}


In the 19 patients with multiple headache phenotypes, the mean follow-up time was 33.42 months (range 13-76). The 50\% response rate at final follow-up was $52.6 \%(n=10)$ which was not significantly different to that of $\mathrm{CCH}$ alone $(\mathrm{p}=0.973)$. Change in daily attack frequency over follow-up is shown in figure $1 \mathrm{~b}$. No difference was seen in change in daily attack frequency between the groups at any time-point. Significant improvements were also seen in attack intensity (28.8\%) and duration (43.5\%) (Table 3).

In responders, 4/8 CM showed improvement (defined as a more than $30 \%$ improvement in moderate-to-severe headache days) and 3/4 SUNHA also showed improvement (defined as a $50 \%$ or more reduction in daily attack frequency). In non-responders, 5/8 CM improved with ONS.

Those with multiple phenotypes showed significant improvements in HIT-6 (-6.10) and EQVAS (10.38) scales but in no other disability, affect or quality of life measurement (Table 4).

\section{Triptan use}

With regards to triptans, 9 patients stopped and 13 were able to decrease their use by more than $50 \%$. Monthly triptan use was $36.82 \pm 32.7$ (range $0-112$ ) prior to and $19.51 \pm 33.07$ (range $0-120)$ post ONS $(\mathrm{p}<0.001)$. The average cost in the UK for injectable Sumatriptan is currently $£ 20.50$ a dose translating to a saving of $£ 407.19 \pm 514.98$ (range 0 -£1722) perpatient per-month. Responders averaged a monthly reduction of $29.37 \pm 25.76$ doses ( $\mathrm{p}<0.001)$ resulting in a saving of $£ 604.37 \pm 519.52$ per-patient per-month (Supplementary Table 3c).

\section{Preventative medication use}

Twenty-seven patients were taking preventative medications at baseline. Four patients were able to stop all preventative medications and in total 17 patients made reductions to their drugs. 


\section{Time to effect and recurrence of attacks}

Time to first reported 50\% improvement in cluster headache attacks was recorded in 37 patients with a mean of 6.86 months \pm 7.33 (range 1-42). Time to reach maximum reported improvement was 21.69 months \pm 15.06 (range 2-54). Eighteen patients had their ONS switched off at some point (13 due to battery depletion, five due to lack of efficacy and one due to explantation). The mean time of ONS switch-off in these subjects was 7.29 months (range 2-18). In 12 of these patients (66.7\%), $\mathrm{CCH}$ worsened within a mean of 6.57 weeks of switch off (range 1-12).

\section{Stimulation settings}

A range of settings was employed in order to achieve the widest area of occipital paranesthesia possible. The range of amplitudes for Medtronic devices was 0.3-5.0V (mean $2.4 \mathrm{~V}$, median $1.5 \mathrm{~V}$ ), pulse width $309-594 \mu \mathrm{sec}$ (mean $418 \mu \mathrm{sec}$ ) and frequency $58-137 \mathrm{~Hz}$ (mean $69.5 \mathrm{~Hz}$ ). For St Jude devices; amplitude range was $0.5-2.7 \mathrm{~mA}$ (mean 2.5mA, median $1.7 \mathrm{~mA}$ ), frequency $70-177 \mathrm{~Hz}$ (mean $96 \mathrm{~Hz}$ ) and pulse width $309-450 \mu \mathrm{sec}$ (mean $415 \mu \mathrm{sec}$ ).

\section{Adverse events}

A total of 81 events were recorded affecting a total of 35 patients (Table 5). The most common event was the need for battery replacement in 19 patients $(37.3 \%)$, however, only 6 of these were deemed unexpected battery failure of under a year. Thirty-eight events required surgical intervention, although accounting for "expected" battery depletion this fell to 19 . One patient $(2.0 \%)$ suffered lead migration and two (3.9\%) from erosion of electrodes through the skin. One infection was reported $(2.0 \%)$ requiring medical intervention only. 


\section{DISCUSSION AND CONCLUSIONS}

This is the largest series with prolonged follow-up period for ONS in $\mathrm{CCH}$. In line with previous series (Table 5) we report that ONS appears to have a positive and sustained effect on otherwise refractory patients $[1 ; 2 ; 4 ; 5 ; 12 ; 14 ; 17]$. The most recent publications of long term follow up from Magis et al. and Leone et al. have both been on long-term follow up of ONS CCH patients $[10 ; 13]$. Magis et al. had a mean of 5.7 years follow up in 10 patients and reported a $70 \%$ reduction in attack frequency but no change in preventative drug use. Leone et al. described a responder rate of $66.7 \%$ in 30 patients with a median follow-up of 6.1 years with $10 \%$ of patients reducing preventative medications. In our group of 51 highly complex patients after mean follow-up of 39.17 months there was a significant improvement in mean attack frequency with 24 patients remaining pain free for prolonged periods of time over follow-up. Overall $52.9 \%$ of all patients exhibited response to ONS at final follow-up. There are a number of reasons why our response rate appears lower than previous series. Firstly, our series had a complex cohort of patients. From available data our patients had a longer duration of chronic disease, had failed more medications and over 1/3 had co-existing headache disorders whereas previous series had $\mathrm{CCH}$ alone. Our data suggests that there is no difference in outcomes of those with or without multiple headache types, a finding that is in opposition to general clinical belief. However, this needs to be clarified in larger cohorts of complex patients. Other factors include possible reporting bias in small series, for example the exclusion of patients whose devices were explanted, and the use of a trial stimulation period that we did not employ. Although no evidence exists for trial stimulation reliably selecting responders, removing those who do not respond may subject remaining patients to positive selection bias. 
Headache disability scales, affect and quality of life scales did show improvement with ONS but those in the quality of life measures were not significant in the whole cohort. However, subgroup analysis of responder vs. non-responders showed a lack of improvement in any field in the non-responder cohort (Supplementary Table 2). The failure to observe significant change across all quality of life measures despite improvements in attack frequency does not indicate lack of efficacy. Similar observations have been made previously in ONS for chronic migraine [3] and is thought to reflect a "burden of normality" wherein patients have difficulty adjusting to the change in their new improved health status. Previous authors have also suggested that a lack of prolonged functional outcome is seen in the long-term following ONS for CM, speculation this is due to the loss of an initial "honeymoon period" in patients[3]. Issues regarding the suitability of the scales in measuring headache populations have also been raised [25]. Specific to our cohort, given that $37.3 \%$ had multiple phenotypes that did not all necessarily respond to ONS a significant proportion of patients would still exhibit a burden from these headaches, even if $\mathrm{CCH}$ had significantly improved. This is supported by a difference in disability scores in those with multiple phenotypes vs. $\mathrm{CCH}$ alone (Table 4).

As in previous series $[2 ; 5 ; 14 ; 15]$, subjects reported a delay of several months before achieving a response (6.86 months) and suffered relapses within weeks of stopping stimulation. These observations suggest that there is a slow but reversible neuroplastic response to successful ONS.

The cost and adverse event profile of ONS for headache treatment have been a cause for controversy in the past. A recent paper estimated the mean treatment costs of ONS to be around $£ 20,500$ per case in a two year period [17]. Although the treatment cost is high, the direct cost from patients on society is significant. In our series, cost per patient in the UK from triptans alone was over $£ 9000$ per year (based on mean triptan use per patient of 37 
doses a month at cost of $£ 20.50$ per dose). Following ONS, we estimate that patients reduced this expense by $£ 4886$ per annum with responders saving an average of $£ 7252$ per year. Nonresponders showed a smaller saving ( $£ 2224$ per annum). This non-significant reduction reflects patients in this group having derived some benefit from the procedure even if they did not reach the dictated $50 \%$ improvement in attack frequency. Shorter or less painful attacks mean patients avoided using triptans or oxygen. This saving combined with a third of patients reducing preventative drugs and the significant improvements in quality of life measures all provide a positive balance to the initial cost of treatment. Using above figures for cost of implant and changes in triptan doses, we estimate that the time to costeffectiveness from reduction in triptan use alone is 3 years in responders (4 years in the whole group and 9 years in non-responders)

Adverse events in our series were much lower than those described in previous cohorts. In small series lead migration rates vary from $7-50 \%[2 ; 5 ; 14 ; 22]$, lead fracture rates from 10 $15 \%[2 ; 14 ; 19]$ and infection $10-20 \%[2 ; 14 ; 19]$. Corresponding rates in our series were $2 \%, 0 \%$ and $2 \%$ respectively. The primary need for repeated surgery post-implant was to replace the battery $(37.3 \%)$, however, the use of rechargeable batteries in recent years should lead to a decrease in surgical interventions and this is something we intend to explore in future publications. Our implants were all conducted by a single highly skilled surgical team. A small number of experienced surgeons conducting larger numbers of procedures have been related to lower adverse event rates [23] and our data supports this.

Weaknesses of the study include the lack of a placebo. This has been a major problem in ONS research, as it is believed paresthesia is a requirement of response. However, it is most unlikely that our observations are explained by placebo alone. The previous intractability, stable time to response across cohorts, sustained response after prolonged follow-up and relapse with ONS failure all argue against a pure placebo response. The placebo controlled 
trials of ONS in migraine suggest a low placebo rate (6\% [21], 17.3\% [24] and 20\% [11]) and there is no reason to expect different rates in cluster headache [18].

Strengths of the study include the large sample, prolonged follow-up, the prospective data collection and the "real life" nature of the data. All subjects were patients in a single specialist center implanted due to clinical need in a healthcare system where ONS was only available as a last-line treatment. The group is different from some previous cohorts in its complex nature and highly intractable nature. A reduction in attack frequency of nearly $50 \%$ in such a highly intractable group, having suffered chronic cluster headache for a mean of 7.88 years and having failed an average of 12.57 prior treatments, is a remarkable achievement.

Our group has recently published the outcomes of a similar complex patient group of 21 patients with $\mathrm{CCH}$ undergoing ventral tegmental area deep brain stimulation, $29 \%$ of which had failed ONS. A reduction in daily attack frequency of $60 \%$ was recorded with a $50 \%$ or more reduction in attack frequency achieved in 52\%. Given the similar response rate and the more invasive nature of deep brain stimulation, it is clear that ONS should be considered first in $\mathrm{CCH}$.

In conclusion, ONS can provide a marked and sustained benefit in highly intractable chronic cluster headache control even after a mean follow up of 3 years. Adverse event rates are low when implants are conducted in highly specialist centers. The initial cost of implantation may be offset by the reduced need for acute medications and improved quality of life. 


\section{REFERENCES}

[1] Burns B, Watkins L, Goadsby PJ. Treatment of medically intractable cluster headache by occipital nerve stimulation: long-term follow-up of eight patients. Lancet 2007;369(9567):1099-1106.

[2] Burns B, Watkins L, Goadsby PJ. Treatment of intractable chronic cluster headache by occipital nerve stimulation in 14 patients. Neurology 2009;72(4):341-345.

[3] Clark SW, Wu C, Boorman DW, Chalouhi N, Zanaty M, Oshinsky M, Young WB, Silberstein SD, Sharan AD. Long-Term Pain Reduction Does Not Imply Improved Functional Outcome in Patients Treated With Combined Supraorbital and Occipital Nerve Stimulation for Chronic Migraine. Neuromodulation 2016;E-Pub ahead of $\operatorname{print(DOI:~10.1111/ner.12400).~}$

[4] de Quintana-Schmidt C, Casajuana-Garreta E, Molet-Teixido J, Garcia-Bach M, Roig C, Clavel-Laria P, Rodriguez-Rodriguez R, Oliver-Abadal B, Bartumeus-Jene F. [Stimulation of the occipital nerve in the treatment of drug-resistant cluster headache]. Rev Neurol 2010;51(1):19-26.

[5] Fontaine D, Christophe Sol J, Raoul S, Fabre N, Geraud G, Magne C, Sakarovitch C, Lanteri-Minet M. Treatment of refractory chronic cluster headache by chronic occipital nerve stimulation. Cephalalgia 2011;31(10):1101-1105.

[6] Goadsby PJ, Schoenen J, Ferrari MD, Silberstein SD, Dodick D. Towards a definition of intractable headache for use in clinical practice and trials. Cephalalgia 2006;26(9):1168-1170.

[7] Headache Classification Committee of the International Headache Society. The International Classification of Headache Disorders, 3rd edition (beta version). Cephalalgia 2013;33(9):629-808. 
[8] Headache Classification Subcommittee of the International Headache Society. The International Classification of Headache Disorders, 2nd edn. Cephalalgia 2004;24(Suppl 1):1-160.

[9] Lambru G, Shanahan P, Watkins L, Matharu MS. Occipital Nerve Stimulation in the Treatment of Medically Intractable SUNCT and SUNA. Pain physician 2014;17(1):29-41.

[10] Leone M, Proietti Cecchini A, Messina G, Franzini A. Long-term occipital nerve stimulation for drug-resistant chronic cluster headache. Cephalalgia 2016.

[11] Lipton R, Goadsby PJ, Cady R, Aurora SK, Grosberg BM, Freitag F, Silberstein S, Whiten DM, Jaax KN. PRISM study: Occipital nerve stimulation for treatmentrefractory migraine. Cephalalgia 2009;29(Suppl 1):30.

[12] Magis D, Allena M, Bolla M, De Pasqua V, Remacle JM, Schoenen J. Occipital nerve stimulation for drug-resistant chronic cluster headache: a prospective pilot study. Lancet Neurol 2007;6(4):314-321.

[13] Magis D, Gerard P, Schoenen J. Invasive occipital nerve stimulation for refractory chronic cluster headache: what evolution at long-term? Strengths and weaknesses of the method. J Headache Pain 2016;17:8.

[14] Magis D, Gerardy PY, Remacle JM, Schoenen J. Sustained effectiveness of occipital nerve stimulation in drug-resistant chronic cluster headache. Headache 2011;51(8):1191-1201.

[15] Magis D, Schoenen J. Advances and challenges in neurostimulation for headaches. Lancet Neurol 2012;11(8):708-719.

[16] Mitsikostas DD, Edvinsson L, Jensen RH, Katsarava Z, Lampl C, Negro A, Osipova V, Paemeleire K, Siva A, Valade D, Martelletti P. Refractory chronic cluster headache: a 
consensus statement on clinical definition from the European Headache Federation. The Journal of Headache and Pain 2014;15(1).

[17] Mueller O, Diener HC, Dammann P, Rabe K, Hagel V, Sure U, Gaul C. Occipital nerve stimulation for intractable chronic cluster headache or migraine: A critical analysis of direct treatment costs and complications. Cephalalgia 2013;33(16):1283-1291.

[18] Nilsson Remahl AI, Laudon Meyer E, Cordonnier C, Goadsby PJ. Placebo response in cluster headache trials: a review. Cephalalgia 2003;23(7):504-510.

[19] Palmisani S, Al-Kaisy A, Arcioni R, Smith T, Negro A, Lambru G, Bandikatla V, Carson E, Martelletti P. A six year retrospective review of occipital nerve stimulation practice--controversies and challenges of an emerging technique for treating refractory headache syndromes. J Headache Pain 2013;14:67.

[20] Russell MB. Epidemiology and genetics of cluster headache. Lancet Neurol 2004;3(5):279-283.

[21] Saper JR, Dodick DW, Silberstein SD, McCarville S, Sun M, Goadsby PJ. Occipital nerve stimulation for the treatment of intractable chronic migraine headache: ONSTIM feasibility study. Cephalalgia 2011;31(3):271-285.

[22] Schwedt TJ, Dodick DW, Hentz J, Trentman TL, Zimmerman RS. Occipital nerve stimulation for chronic headache--long-term safety and efficacy. Cephalalgia 2007;27(2):153-157.

[23] Sharan A, Huh B, Narouze S, Trentman T, Mogilner A, Vaisman J, Ordia J, Deer T, Venkatesan L, Slavin K. Analysis of Adverse Events in the Management of Chronic Migraine by Peripheral Nerve Stimulation. Neuromodulation 2015;18(4):305-312.

[24] Silberstein SD, Dodick DW, Saper J, Huh B, Slavin KV, Sharan A, Reed K, Narouze S, Mogilner A, Goldstein J, Trentman T, Vaisma J, Ordia J, Weber P, Deer T, Levy R, Diaz RL, Washburn SN, Mekhail N. Safety and efficacy of peripheral nerve 
stimulation of the occipital nerves for the management of chronic migraine: results from a randomized, multicenter, double-blinded, controlled study. Cephalalgia 2012;32(16):1165-1179.

[25] Solomon GD. Evolution of the measurement of quality of life in migraine. Neurology 1997;48(3 Suppl 3):10S-15S. 


\begin{tabular}{|c|c|}
\hline & $\mathrm{N}=51$ \\
\hline \multicolumn{2}{|l|}{ ONS Manufacturer } \\
\hline Medtronic & $48(94.1 \%)$ \\
\hline St Jude Medical & $3(5.9 \%)$ \\
\hline \multicolumn{2}{|l|}{ IPG } \\
\hline Standard & $8(15.7 \%)$ \\
\hline Rechargeable & $27(52.9 \%)$ \\
\hline Standard changed to rechargeable & $16(31.4 \%)$ \\
\hline \multicolumn{2}{|l|}{ Electrodes } \\
\hline Octad & $51(100 \%)$ \\
\hline
\end{tabular}

Table 1: Information on the occipital nerve stimulator systems implanted 


\begin{tabular}{|c|c|}
\hline Age & $\begin{array}{l}47.78 \text { years }( \pm 9.73) \\
\text { Range } 31-70\end{array}$ \\
\hline $\begin{array}{r}\text { Male } \\
\text { Female }\end{array}$ & $\begin{array}{l}35(68.6 \%) \\
16(31.4 \%)\end{array}$ \\
\hline Attack Side & $\begin{array}{l}32(62.7 \%) \\
15(29.4 \%) \\
4(7.8 \%)\end{array}$ \\
\hline $\begin{array}{r}\text { Strictly unilateral } \\
\text { Unilateral but side variable } \\
\text { Bilateral }\end{array}$ & $\begin{array}{l}41(80.4 \%) \\
7(13.7 \%) \\
3(5.9 \%)\end{array}$ \\
\hline $\begin{array}{l}\text { Pattern } \\
\text { Episodic transformed to chronic } \\
\text { Chronic from onset }\end{array}$ & $\begin{array}{l}30(58 \%) \\
21(42 \%)\end{array}$ \\
\hline Duration from onset of Cluster Headache & $\begin{array}{l}14.63 \text { years }( \pm 11.0) \\
\text { Range } 2-48\end{array}$ \\
\hline $\begin{array}{l}\text { Duration from onset of Chronic } \\
\text { phase }\end{array}$ & $\begin{array}{l}7.88 \text { years }( \pm 6.44) \\
\text { Range } 2-43\end{array}$ \\
\hline Co-existent headache phenotypes & $19(37.3 \%)$ \\
\hline Number of headache phenotypes & $\begin{array}{l}32(62.7 \%) \\
16(31.4 \%) \\
3(5.9 \%)\end{array}$ \\
\hline $\begin{array}{r}\text { Co-existent phenotypes } \\
\mathrm{CCH}+\mathrm{CM} \\
\mathrm{CCH}+\mathrm{SUNCT} / \mathrm{SUNA} \\
\mathrm{CCH}+\mathrm{CM}+\mathrm{SUNCT} / \mathrm{SUNA}\end{array}$ & $\begin{array}{l}13(25.5 \%) \\
3(5.9 \%) \\
3(5.9 \%)\end{array}$ \\
\hline $\begin{array}{l}\text { Mean number preventatives prior to } \\
\text { ONS }\end{array}$ & $\begin{array}{l}12.57( \pm 2.91) \\
\text { Range } 7-21\end{array}$ \\
\hline Response to GON block prior to ONS & $21(41.2 \%)$ \\
\hline Follow up since implant & \begin{tabular}{|l}
39.17 months $( \pm 19.04)$ \\
Range 2-81
\end{tabular} \\
\hline
\end{tabular}

$\mathrm{CCH}$, chronic cluster headache; CM, chronic migraine; GON, Greater Occipital Nerve; ONS, Occipital nerve Stimulation; SUNA, short lasting unilateral neuralgiform headache attacks with autonomic features; SUNCT, short lasting unilateral neuralgiform headache attacks with conjunctival injection and tearing

Table 2: Demographic data 


\begin{tabular}{|c|c|c|c|c|c|}
\hline Outcome Measure & $\begin{array}{l}\text { Prior } \\
\text { ONS } \\
(n=51)\end{array}$ & $\begin{array}{l}\text { Post } \\
\text { ONS } \\
(n=51)\end{array}$ & $\begin{array}{l}\text { Percentage } \\
\text { Change }\end{array}$ & $\begin{array}{l}\text { Mean Difference } \\
(95 \% \text { CI })\end{array}$ & P Value \\
\hline \multicolumn{6}{|l|}{ Whole Cohort } \\
\hline $\begin{array}{l}\text { Mean daily attacks } \\
\text { (SD) } \\
\text { Range }\end{array}$ & $\begin{array}{l}3.73 \\
( \pm 1.83) \\
1-8\end{array}$ & $\begin{array}{l}2.12 \\
( \pm 2.28) \\
0-8\end{array}$ & $\begin{array}{l}46.1 \% \\
( \pm 43.69) \\
0-100\end{array}$ & $1.61(0.88,2.34)$ & $<0.001 *$ \\
\hline $\begin{array}{l}\text { Mean attack } \\
\text { intensity (SD) } \\
\text { Range (VRS) }\end{array}$ & $\begin{array}{l}8.43 \\
( \pm 1.61) \\
5-10\end{array}$ & $\begin{array}{l}6.17 \\
( \pm 3.54) \\
0-10\end{array}$ & $\begin{array}{l}26.4 \% \\
( \pm 37.47) \\
0-100\end{array}$ & $2.27(1.18,3.35)$ & $<0.001 *$ \\
\hline $\begin{array}{l}\text { Mean attack } \\
\text { duration (SD) } \\
\text { Range (hours) }\end{array}$ & $\begin{array}{l}1.66 \\
( \pm 1.62) \\
0.3-10.5\end{array}$ & $\begin{array}{l}0.85 \\
( \pm 0.98) \\
0.0-5.5\end{array}$ & $\begin{array}{l}43.3 \% \\
( \pm 39.27) \\
0-100\end{array}$ & $0.801(0.46,1.15)$ & $<0.001 *$ \\
\hline \multicolumn{6}{|l|}{ CCH Alone $(n=32)$} \\
\hline $\begin{array}{l}\text { Mean daily attacks } \\
\text { (SD) } \\
\\
\text { Range }\end{array}$ & $\begin{array}{l}3.88 \\
( \pm 1.69) \\
1-8 \\
\end{array}$ & $\begin{array}{l}1.91 \\
( \pm 2.10) \\
0-7 \\
\end{array}$ & $\begin{array}{l}49.5 \% \\
( \pm 43.84) \\
0-100 \\
\end{array}$ & $1.96(1.03,2.90)$ & $<0.001 *$ \\
\hline $\begin{array}{l}\text { Mean attack } \\
\text { intensity (SD) } \\
\text { Range (VRS) }\end{array}$ & $\begin{array}{l}8.22 \\
( \pm 1.73) \\
5-10 \\
\end{array}$ & $\begin{array}{l}6.64 \\
( \pm 3.20) \\
0-10 \\
\end{array}$ & $\begin{array}{l}25.0 \% \\
( \pm 36.56) \\
0-100 \\
\end{array}$ & $1.57(0.34,2.81)$ & $0.014 *$ \\
\hline $\begin{array}{l}\text { Mean attack } \\
\text { duration (SD) } \\
\text { Range (hours) }\end{array}$ & $\begin{array}{l}1.54 \\
( \pm 1.05) \\
0.3-4.0\end{array}$ & $\begin{array}{l}0.86 \\
( \pm 0.78) \\
0.0-2.8\end{array}$ & $\begin{array}{l}43.2 \% \\
( \pm 38.46) \\
0-100\end{array}$ & $0.68( \pm 0.30,1.06)$ & $<0.001 *$ \\
\hline \multicolumn{6}{|c|}{ Multiple Phenotypes $(n=19)$} \\
\hline $\begin{array}{l}\text { Mean daily attacks } \\
\text { (SD) } \\
\text { Range }\end{array}$ & $\begin{array}{l}3.47 \\
( \pm 2.06) \\
1-8\end{array}$ & $\begin{array}{l}2.47 \\
( \pm 2.59) \\
0-8\end{array}$ & $\begin{array}{l}40.3 \% \\
( \pm 43.97) \\
0-100\end{array}$ & $1.00(0.24,2.24)$ & $0.036^{*}$ \\
\hline $\begin{array}{l}\text { Mean attack } \\
\text { intensity (SD) } \\
\text { Range (VRS) }\end{array}$ & $\begin{array}{l}8.79 \\
( \pm 1.34) \\
6-10\end{array}$ & $\begin{array}{l}5.37 \\
( \pm 4.00) \\
0-10\end{array}$ & $\begin{array}{l}28.8 \% \\
( \pm 39.83) \\
0-100\end{array}$ & $3.42(1.32,5.51)$ & $0.003 *$ \\
\hline $\begin{array}{l}\text { Mean attack } \\
\text { duration (SD) } \\
\text { Range (hours) }\end{array}$ & $\begin{array}{l}1.84 \\
( \pm 2.32) \\
0.3-10.5\end{array}$ & $\begin{array}{l}0.848 \\
( \pm 1.27) \\
0.0-5.5\end{array}$ & $\begin{array}{l}43.5 \% \\
( \pm 41.70) \\
0-100\end{array}$ & $0.99(0.28,1.71)$ & $0.009 *$ \\
\hline
\end{tabular}

$\mathrm{CCH}$, chronic cluster headache; CI, Confidence interval; ONS, Occipital nerve Stimulation; SD, Standard deviation; VRS, verbal rating scale

Table 3: Summary of attack outcome measures 


\begin{tabular}{|c|c|c|c|c|}
\hline & Pre-ONS & Post-ONS & Change in score & P value \\
\hline \multicolumn{5}{|l|}{ Whole Cohort $(n=51)$} \\
\hline $\begin{array}{r}\text { MIDAS }(\mathbf{n}=\mathbf{5 1}) \\
\text { Mean }( \pm \text { SD }) \\
\text { Range }\end{array}$ & $\begin{array}{c}149.84( \pm 89.10) \\
0-270\end{array}$ & $\begin{array}{c}114.92( \pm 106.66) \\
0-270\end{array}$ & $34.92( \pm 100.19)$ & $0.016^{*}$ \\
\hline $\begin{array}{r}\text { HIT-6 }(=\mathbf{5 1}) \\
\text { Mean }( \pm \text { SD }) \\
\text { Range }\end{array}$ & $\begin{array}{c}67.73( \pm 6.08) \\
53-80 \\
\end{array}$ & $\begin{array}{c}60.68( \pm 13.07) \\
10-78 \\
\end{array}$ & $7.05( \pm 11.08)$ & $<0.001 *$ \\
\hline $\begin{array}{r}\text { HAD-A }(\mathbf{n}=\mathbf{5 1}) \\
\text { Mean }( \pm \mathrm{SD}) \\
\text { Range }\end{array}$ & $\begin{array}{c}12.16( \pm 5.005) \\
1-21\end{array}$ & $\begin{array}{c}10.12( \pm 5.41) \\
0-21 \\
\end{array}$ & $2.04( \pm 5.63)$ & $0.013^{*}$ \\
\hline $\begin{array}{r}\text { HAD-D }(\mathbf{n}=\mathbf{5 1}) \\
\text { Mean }( \pm \mathrm{SD}) \\
\text { Range }\end{array}$ & $\begin{array}{c}12.04( \pm 4.68) \\
1-21\end{array}$ & $\begin{array}{c}9.22( \pm 6.10) \\
01-21\end{array}$ & $2.82( \pm 5.56)$ & $0.001 *$ \\
\hline $\begin{array}{r}\text { BDI-II }(\mathbf{n = 4 9}) \\
\text { Mean }( \pm \text { SD }) \\
\text { Range }\end{array}$ & $\begin{array}{c}27.59( \pm 14.45) \\
0-55\end{array}$ & $\begin{array}{c}22.82( \pm 15.98) \\
0-56\end{array}$ & $4.77( \pm 13.66)$ & $0.018^{*}$ \\
\hline $\begin{array}{r}\text { EQ5D }(\mathbf{n = 4 9 )} \\
\text { Mean }( \pm \text { SD }) \\
\text { Range }\end{array}$ & $\begin{array}{c}0.69( \pm 0.11) \\
0.55-1.00\end{array}$ & $\begin{array}{c}0.69( \pm 0.15) \\
0.18-1.00\end{array}$ & $0( \pm 0.11)$ & 1.00 \\
\hline $\begin{array}{r}\text { EQ-VAS }(\mathbf{n = 4 9 )} \\
\text { Mean }( \pm \mathrm{SD}) \\
\text { Range }\end{array}$ & $\begin{array}{c}49.75( \pm 23.24) \\
0-95\end{array}$ & $\begin{array}{c}52.42( \pm 27.62) \\
5-95\end{array}$ & $-2.67( \pm 17.08)$ & 0.285 \\
\hline $\begin{array}{r}\text { SF-36 P }(\mathbf{n}=\mathbf{5 1}) \\
\text { Mean }( \pm \mathrm{SD}) \\
\text { Range }\end{array}$ & $\begin{array}{c}32.12( \pm 9.97) \\
13.70-52.30 \\
\end{array}$ & $\begin{array}{c}33.82( \pm 11.80) \\
11.80-55.70\end{array}$ & $-1.70( \pm 9.14)$ & 0.191 \\
\hline $\begin{array}{r}\text { SF-36 M }(\mathbf{n = 5 1}) \\
\text { Mean }( \pm \text { SD }) \\
\text { Range }\end{array}$ & $\begin{array}{c}34.14( \pm 12.97) \\
15.3-58.5\end{array}$ & $\begin{array}{c}38.34( \pm 14.79) \\
14.70-62.70\end{array}$ & $-4.20( \pm 13.95)$ & $0.036^{*}$ \\
\hline
\end{tabular}




\begin{tabular}{|c|c|c|c|c|}
\hline \multicolumn{5}{|l|}{ CCH alone $(n=32)$} \\
\hline $\begin{array}{r}\text { MIDAS }(\mathbf{n}=\mathbf{3 2}) \\
\text { Mean }( \pm \text { SD }) \\
\text { Range }\end{array}$ & $\begin{array}{c}156.25( \pm 91.19) \\
0-270\end{array}$ & $\begin{array}{c}108.59( \pm 111.35) \\
0-270\end{array}$ & $47.66( \pm 108.65)$ & $0.019 *$ \\
\hline $\begin{array}{r}\text { HIT-6 }(=\mathbf{3 2}) \\
\text { Mean }( \pm \text { SD }) \\
\text { Range } \\
\end{array}$ & $\begin{array}{c}67.91( \pm 6.31) \\
53-80 \\
\end{array}$ & $\begin{array}{c}60.28( \pm 14.04) \\
10-78 \\
\end{array}$ & $7.62( \pm 11.94)$ & $0.001 *$ \\
\hline $\begin{array}{r}\text { HAD-A }(\mathbf{n}=\mathbf{3 2}) \\
\text { Mean }( \pm \text { SD }) \\
\text { Range }\end{array}$ & $\begin{array}{c}12.81( \pm 4.30) \\
3-21\end{array}$ & $\begin{array}{c}10.78(+4.67) \\
0-19\end{array}$ & $2.03( \pm 5.43)$ & $0.043 *$ \\
\hline $\begin{array}{r}\text { HAD-D }(\mathbf{n}=\mathbf{3 2}) \\
\text { Mean }( \pm \text { SD }) \\
\text { Range }\end{array}$ & $\begin{array}{c}12.28( \pm 4.48) \\
1-20 \\
\end{array}$ & $\begin{array}{c}9.47( \pm 6.02) \\
0-20\end{array}$ & $2.81( \pm 5.39)$ & $0.006^{*}$ \\
\hline $\begin{array}{r}\text { BDI-II }(\mathbf{n = 3 2}) \\
\text { Mean }( \pm \text { SD }) \\
\text { Range }\end{array}$ & $\begin{array}{c}28.34( \pm 14.23) \\
0-52\end{array}$ & $\begin{array}{c}22.30( \pm 15.75) \\
0-53\end{array}$ & $6.43( \pm 11.67)$ & $0.005^{*}$ \\
\hline $\begin{array}{r}\text { EQ5D }(\mathbf{n = 3 0}) \\
\text { Mean }( \pm \text { SD }) \\
\text { Range }\end{array}$ & $\begin{array}{c}0.70( \pm 0.11) \\
0.55-1.00\end{array}$ & $\begin{array}{c}0.70( \pm 0.13) \\
0.55-1.00\end{array}$ & $0.00( \pm 0.09)$ & 0.908 \\
\hline $\begin{array}{r}\text { EQ-VAS }(\mathbf{n}=\mathbf{3 0}) \\
\text { Mean }( \pm \text { SD }) \\
\text { Range }\end{array}$ & $\begin{array}{c}56.13( \pm 19.89) \\
20-90 \\
\end{array}$ & $\begin{array}{c}55.00( \pm 24.25) \\
10-95\end{array}$ & $1.96( \pm 12.74)$ & 0.405 \\
\hline $\begin{array}{r}\text { SF-36 P }(\mathbf{n}=32) \\
\text { Mean }( \pm \text { SD }) \\
\text { Range }\end{array}$ & $\begin{array}{c}33.52( \pm 9.40) \\
18.8-52.3\end{array}$ & $\begin{array}{c}35.06( \pm 10.82) \\
11.80-53.20\end{array}$ & $-1.54( \pm 8.93)$ & 0.337 \\
\hline $\begin{array}{r}\text { SF-36 M (n=32) } \\
\text { Mean }( \pm \text { SD }) \\
\text { Range }\end{array}$ & $\begin{array}{c}33.99( \pm 13.38) \\
16.60-58.20\end{array}$ & $\begin{array}{c}38.02( \pm 14.46) \\
14.70-62.70\end{array}$ & $-4.02( \pm 12.89)$ & 0.087 \\
\hline
\end{tabular}

Pg. 23 


\begin{tabular}{|c|c|c|c|c|}
\hline $\begin{array}{r}\text { MIDAS }(\mathbf{n = 1 9 )} \\
\text { Mean }( \pm \mathrm{SD}) \\
\text { Range }\end{array}$ & $\begin{array}{c}139.05( \pm 86.80) \\
8-270\end{array}$ & $\begin{array}{c}125.58( \pm 100.28) \\
0-270\end{array}$ & $13.47( \pm 82.34)$ & 0.485 \\
\hline $\begin{array}{r}\text { HIT-6 (=19) } \\
\text { Mean }( \pm \text { SD }) \\
\text { Range }\end{array}$ & $\begin{array}{c}67.42( \pm 5.83) \\
58-78\end{array}$ & $\begin{array}{c}61.32( \pm 11.58) \\
42-78\end{array}$ & $6.10( \pm 9.70)$ & $0.013 *$ \\
\hline $\begin{array}{r}\text { HAD-A }(\mathbf{n}=\mathbf{1 9}) \\
\text { Mean }( \pm \mathrm{SD}) \\
\text { Range }\end{array}$ & $\begin{array}{c}11.05( \pm 5.96) \\
1-20\end{array}$ & $\begin{array}{c}9.00( \pm 6.44) \\
0-21\end{array}$ & $2.05( \pm 9.70)$ & 0.160 \\
\hline $\begin{array}{r}\text { HAD-D }(\mathbf{n}=\mathbf{1 9}) \\
\text { Mean }( \pm \mathrm{SD}) \\
\text { Range }\end{array}$ & $\begin{array}{c}11.63( \pm 5.39) \\
1-21\end{array}$ & $\begin{array}{c}8.79(6.38) \\
0-21\end{array}$ & $2.84( \pm 5.99)$ & 0.053 \\
\hline $\begin{array}{r}\text { BDI-II }(\mathbf{n}=\mathbf{1 9}) \\
\text { Mean }( \pm \text { SD }) \\
\text { Range }\end{array}$ & $\begin{array}{c}25.79( \pm 14.37) \\
5-55\end{array}$ & $\begin{array}{c}23.63( \pm 16.74) \\
1-56\end{array}$ & $2.158( \pm 16.33)$ & 0.572 \\
\hline $\begin{array}{r}\text { EQ5D }(\mathbf{n = 1 9}) \\
\text { Mean }( \pm \text { SD }) \\
\text { Range }\end{array}$ & $\begin{array}{c}0.68( \pm 0.10) \\
0.55-0.84\end{array}$ & $\begin{array}{c}0.68( \pm 0.17) \\
0.18-1.00\end{array}$ & $0.00( \pm 0.14)$ & 0.925 \\
\hline $\begin{array}{r}\text { EQ-VAS }(\mathbf{n = 1 9 )} \\
\text { Mean }( \pm \mathrm{SD}) \\
\text { Range }\end{array}$ & $\begin{array}{c}39.11( \pm 25.02) \\
0-95\end{array}$ & $\begin{array}{c}49.50( \pm 33.09) \\
5-95\end{array}$ & $-10.38( \pm 20.71)$ & $0.048 *$ \\
\hline $\begin{array}{r}\text { SF-36 P }(\mathbf{n = 1 9 )} \\
\text { Mean }( \pm \mathrm{SD}) \\
\text { Range }\end{array}$ & $\begin{array}{c}29.77( \pm 10.70) \\
13.70-49.00\end{array}$ & $\begin{array}{c}31.73( \pm 13.33) \\
13.70-55.70\end{array}$ & $-1.96( \pm 9.71)$ & 0.390 \\
\hline $\begin{array}{r}\text { SF-36 M (n=19) } \\
\text { Mean }( \pm \text { SD }) \\
\text { Range }\end{array}$ & $\begin{array}{c}34.38( \pm 12.61) \\
15.30-58.50\end{array}$ & $\begin{array}{c}38.90( \pm 15.69) \\
14.80-59.50\end{array}$ & $-4.51( \pm 15.94)$ & 0.233 \\
\hline
\end{tabular}

BDI-II, Beck Depression Inventory II; CCH, Chronic cluster headache; EQ5D, Euro-QoL 5D Index; Euro-VAS, Euro-QoL visual analogue score; HAD-A, Hospital Anxiety and Hospital Depression Scores - Anxiety component; HAD-D, Hospital Anxiety and Hospital Depression Scores - Depression component; HIT-6, Headache Impact Test 6 Score; MIDAS, Migraine Disability Assessment Score; ONS, Occipital Nerve Stimulation; SD, Standard Deviation 
Table 4: Summary of headache-related disability and mental state scores 


\begin{tabular}{|c|c|c|}
\hline & Adverse Event & Total Events \\
\hline \multirow{11}{*}{ Hardware Related } & Lead migration & $1(2 \%)$ \\
\hline & Electrode erosion & $2(4 \%)$ \\
\hline & ONS system revision & $6(12 \%)$ \\
\hline & Rechargeable system & $2(4 \%)$ \\
\hline & Lead revisions (lead tethering) & $2(4 \%)$ \\
\hline & IPG revision secondary to pain & $2(4 \%)$ \\
\hline & Explantation & $4(8 \%)$ \\
\hline & Efficacy & $3(6 \%)$ \\
\hline & Lead tethering causing neck pain & $1(2 \%)$ \\
\hline & Battery depletion (Failure in under one year) & $6(12 \%)$ \\
\hline & Battery replacement at any time & $19(37.3 \%)$ \\
\hline \multicolumn{2}{|c|}{ Total Hardware Related Events } & 38 \\
\hline \multirow{8}{*}{ Biological } & $\begin{array}{l}\text { Infection (superficial wound infection) } \\
\text { (surgical action } \mathrm{n}=0 \text { ) }\end{array}$ & $1(2 \%)$ \\
\hline & $\begin{array}{l}\text { Pain over IPG/lead/wound sites } \\
\text { (surgical action } n=2 \text { ) }\end{array}$ & $12(24 \%)$ \\
\hline & $\begin{array}{l}\text { Neck stiffness } \\
\text { (surgical action } n=0 \text { ) }\end{array}$ & $8(16 \%)$ \\
\hline & Allergy to surgical material & $2(8 \%)$ \\
\hline & Wound site complication & $3(6 \%)$ \\
\hline & Keloid scar & $2(4 \%)$ \\
\hline & Idiopathic Urticaria & $1(2 \%)$ \\
\hline & (surgical action $\mathrm{n}=0$ ) & \\
\hline \multicolumn{2}{|c|}{ Total Biological Related Events } & 26 \\
\hline Stimulator Associated & $\begin{array}{l}\text { Undesirable changes in stimulation } \\
\text { (surgical action } n=0)\end{array}$ & $17(33 \%)$ \\
\hline \multicolumn{2}{|c|}{ Total Stimulator Associated Events } & 17 \\
\hline TOTAL & & 81 events \\
\hline
\end{tabular}

IPG, implantable pulse generator; ONS, Occipital nerve stimulator

Table 5: Adverse events 


\begin{tabular}{|c|c|c|c|c|c|c|c|c|c|c|}
\hline Study & $\begin{array}{l}\text { Num } \\
\text { ber } \\
\text { of } \\
\text { Patie } \\
\text { nts }\end{array}$ & $\begin{array}{l}\text { Mea } \\
\text { n } \\
\text { age } \\
\text { (yea } \\
\text { rs) }\end{array}$ & $\begin{array}{l}\text { Chro } \\
\text { nic } \\
\text { Durat } \\
\text { ion } \\
\text { (years } \\
\text { ) }\end{array}$ & $\begin{array}{l}\text { Mean } \\
\text { Number } \\
\text { Preventa } \\
\text { tives } \\
\text { Failed }\end{array}$ & $\begin{array}{l}\text { Mean } \\
\text { Follo } \\
\text { w-up } \\
\text { [rang } \\
\text { e] } \\
\text { (mont } \\
\text { hs) }\end{array}$ & $\begin{array}{l}\text { Patien } \\
\text { ts } \\
\text { impro } \\
\text { ved } \\
>50 \%\end{array}$ & $\begin{array}{l}\text { Chang } \\
\text { e } \\
\text { attack } \\
\text { Freque } \\
\text { ncy }\end{array}$ & $\begin{array}{l}\text { Chan } \\
\text { ge } \\
\text { attac } \\
\text { k } \\
\text { Seve } \\
\text { rity }\end{array}$ & $\begin{array}{l}\text { Chan } \\
\text { ge } \\
\text { attac } \\
\text { k } \\
\text { Durat } \\
\text { ion }\end{array}$ & $\begin{array}{l}\text { Prevent } \\
\text { ative } \\
\text { Treatm } \\
\text { ent } \\
\text { Reducti } \\
\text { on }\end{array}$ \\
\hline $\begin{array}{l}\text { Magis } \\
2007^{15}, 2 \\
011^{12}\end{array}$ & 14 & 47.6 & 7.07 & $>4^{*}$ & $\begin{array}{l}36.62 \\
{[11-} \\
64]\end{array}$ & $\begin{array}{l}12 / 14 \\
(86 \%)\end{array}$ & $-94.6 \%$ & $\begin{array}{l}+2.3 \\
\%\end{array}$ & N/A & $4 / 14$ \\
\hline $\begin{array}{l}\text { Burns } \\
2007^{16}, 2 \\
009^{10}\end{array}$ & 14 & 44 & 6 & $>4 * *$ & $\begin{array}{l}17.5 \\
{[4-35]}\end{array}$ & $\begin{array}{l}10 / 14 \\
(71 \%)\end{array}$ & $-33 \%$ & $+8 \%$ & $-23 \%$ & $\begin{array}{l}6 / 14 \\
\text { (triptans } \\
\text { ) }\end{array}$ \\
\hline $\begin{array}{l}\text { De } \\
\text { Quinta } \\
\text { na } \\
2010^{17}\end{array}$ & 4 & 42 & - & - & $6+$ & $\begin{array}{l}4 / 4 \\
(100 \% \\
)\end{array}$ & $-56 \%$ & $-48 \%$ & $\begin{array}{l}- \\
63.8 \%\end{array}$ & $3 / 14$ \\
\hline $\begin{array}{l}\text { Fontain } \\
\text { e } \\
2011^{11}\end{array}$ & 13 & 44.6 & 9.8 & $>4 *$ & $\begin{array}{l}14.6 \\
{[3-34]}\end{array}$ & $\begin{array}{l}10 / 13 \\
(76 \%)\end{array}$ & $-68 \%$ & $-49 \%$ & N/A & $8 / 13$ \\
\hline $\begin{array}{l}\text { Muelle } \\
\text { r } \\
2013^{20}\end{array}$ & 24 & 30 & - & $>3$ & $\begin{array}{l}21.5 \\
{[4-47]}\end{array}$ & $\begin{array}{l}21 / 24 \\
(88 \%)\end{array}$ & $-40 \%$ & $-38 \%$ & N/A & $\begin{array}{l}- \\
(40 \% \\
\text { reductio } \\
\mathrm{n} \quad \text { daily } \\
\text { triptan } \\
\text { dose })\end{array}$ \\
\hline $\begin{array}{l}\text { Magis } \\
2016^{13}\end{array}$ & 10 & 47.6 & 7 & $>4 *$ & $\begin{array}{l}71 \\
{[54-} \\
103]\end{array}$ & $\begin{array}{l}9 / 10 \\
(90 \%)\end{array}$ & $-70.8 \%$ & N/A & N/A & $4 / 10$ \\
\hline $\begin{array}{l}\text { Leone } \\
2016^{10}\end{array}$ & 30 & 42 & 6.7 & N/A & $\begin{array}{l}73.2 \\
{[2-11]}\end{array}$ & $\begin{array}{l}20 / 30 \\
(66.7 \\
\%)\end{array}$ & N/A & N/A & N/A & 0 \\
\hline $\begin{array}{l}\text { Our } \\
\text { Study }\end{array}$ & 51 & $\begin{array}{l}47.7 \\
8\end{array}$ & 7.88 & 12.57 & $\begin{array}{l}39.17 \\
{[2-81]}\end{array}$ & $\begin{array}{l}27 / 51 \\
(52.9 \\
\%)\end{array}$ & $\begin{array}{l}- \\
46.14 \\
\%\end{array}$ & $\begin{array}{l}- \\
26.47 \\
\%\end{array}$ & $\begin{array}{l} \\
43.35 \\
\%\end{array}$ & $\begin{array}{l}21 / 27 \dagger \\
(26 / \\
51 t r i p t a \\
\text { ns })\end{array}$ \\
\hline
\end{tabular}

*As per ICHD definition of "intractable chronic cluster headache"; **Patients failed mean 9 preventatives in 2007 study; ${ }^{+}$No range given; $\uparrow 31$ patients on preventative medication at implant

Table 6: Comparison of outcomes for occipital nerve stimulation in chronic cluster headache 


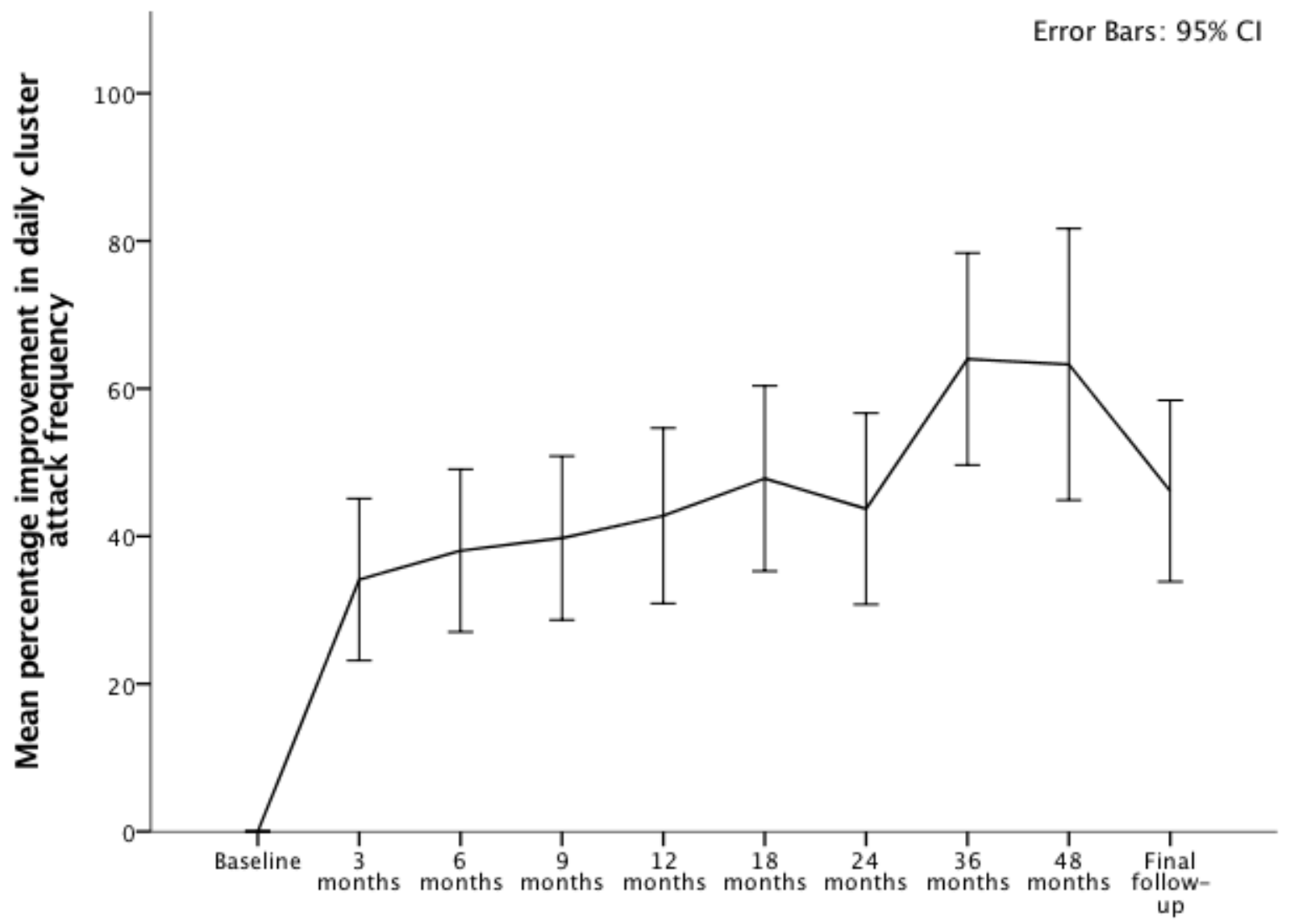

Follow-up point

Figure 1a: Improvement of daily cluster attack frequency of entire cohort over follow-up 


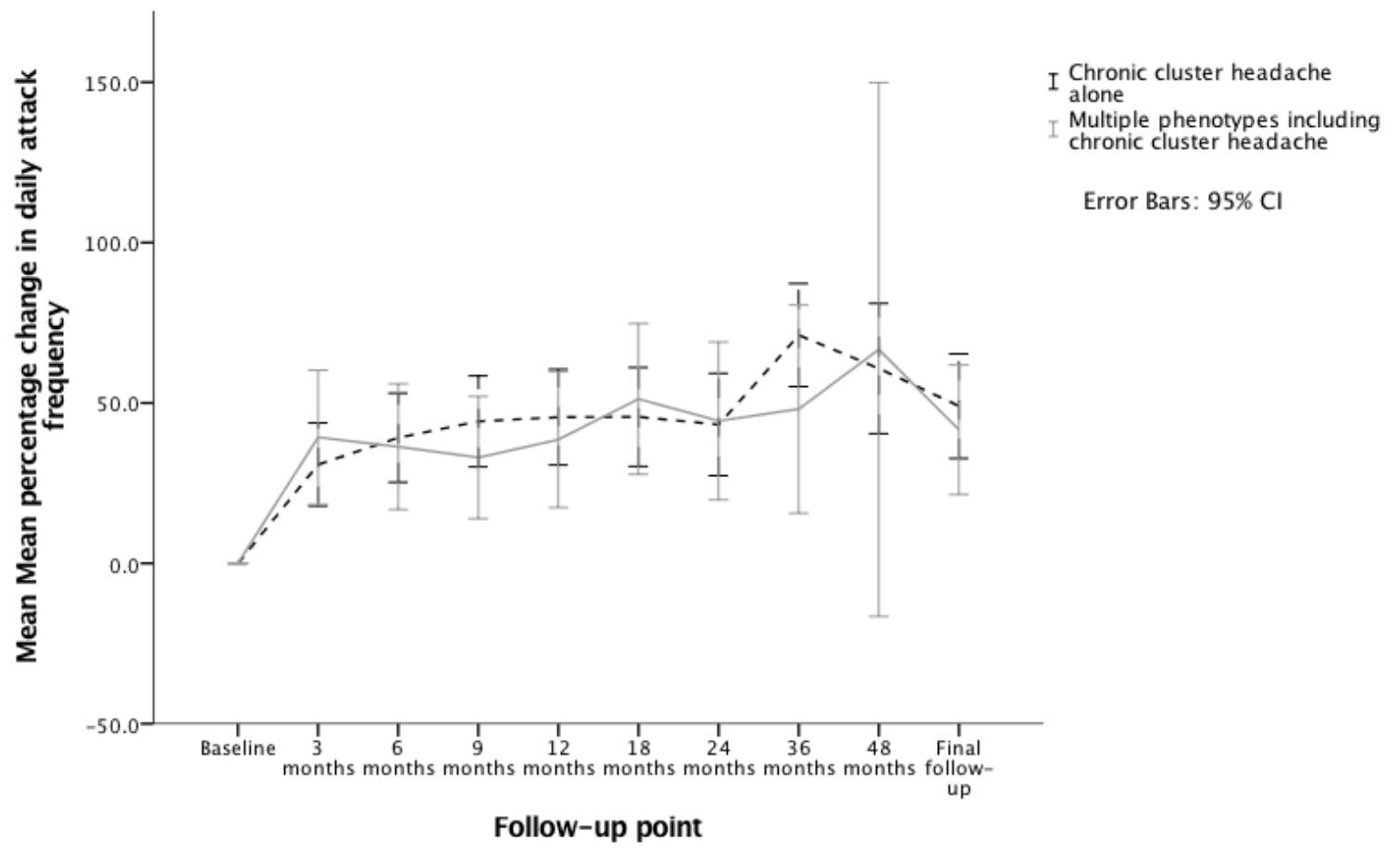

\begin{tabular}{|l|l|l|l|l|l|l|l|l|l|l|}
\hline $\begin{array}{l}\text { Follow-up } \\
\text { (months) }\end{array}$ & Baseline & 3 & 6 & 9 & 12 & 18 & 24 & 36 & 48 & Final follow- \\
\hline $\begin{array}{l}\text { CCH alone } \\
\begin{array}{l}\text { Multiple } \\
\text { Phenotypes }\end{array}\end{array}$ & 32 & 32 & 31 & 31 & 31 & 28 & 24 & 21 & 16 & 32 \\
\hline \begin{tabular}{l} 
p-value \\
\hline
\end{tabular} & 19 & 19 & 19 & 19 & 16 & 14 & 8 & 3 & 19 \\
\hline
\end{tabular}

$\mathrm{CCH}$, chronic cluster headache; N/A, not applicable

Figure 1b: Improvement in daily cluster attack frequency of those with chronic cluster headache alone compared to those with multiple phenotypes over follow-up. Table provides number of subjects included at each time point and p-value for difference in improvement between the groups.

Figure 1: Changes in improvement in daily cluster headache attack frequency following occipital nerve stimulation 


\begin{tabular}{|l|c|c|c|}
\hline & $\begin{array}{l}\text { Number of patient } \\
\text { who have tried drug } \\
(\%)\end{array}$ & Daily dose range (mg) & $\begin{array}{l}\text { Mean maximum daily } \\
\text { dose (mg) }\end{array}$ \\
\hline Verapamil & $51(100)$ & $240-1200$ & 762 \\
\hline Lithium & $49(96.8)$ & $200-2800$ & 1014 \\
\hline Topiramate & $39(76.2)$ & $25-800$ & 232 \\
\hline Melatonin & $39(76.2)$ & $4-15$ & 13 \\
\hline Gabapentin & $47(92.1)$ & $300-3600$ & 2155 \\
\hline Pregabalin & $34(66.7)$ & $150-1000$ & 491 \\
\hline Valproate & $35(68.3)$ & $50-3000$ & 57 \\
\hline Methysergide & $46(92.1)$ & $2-27$ & - \\
\hline Baclofen & $9(17.5)$ & $10-90$ & - \\
\hline Corticosteroid & $36(69.8)$ & - & - \\
\hline IV DHE & $44(85.7)$ & - & \\
\hline GONB & $48(93.7)$ & - & \\
\hline
\end{tabular}

GONB, greater occipital nerve block; IV DHE, intravenous dihydroergotamine;

Supplementary Table 1. Medications taken for cluster headache prior to occipital nerve stimulation 


\begin{tabular}{|c|c|c|c|c|c|c|c|c|c|c|}
\hline & \multicolumn{5}{|c|}{ Responders $(\mathrm{n}=27)$} & \multicolumn{5}{|c|}{ Non-Responders $(n=24)$} \\
\hline & & Pre-ONS & & Post-ONS & $P$ value & & Pre-ONS & & Post-ONS & $P$ value \\
\hline \multicolumn{11}{|c|}{ Headache Disability Scores } \\
\hline MIDAS & $\mathrm{N}=27$ & $153.11( \pm 96.26)$ & $\mathrm{N}=27$ & $79.04( \pm 101.36)$ & $0.001 *$ & $\mathrm{~N}=24$ & $146.17( \pm 82.21)$ & $\mathrm{N}=24$ & $155.29( \pm 99.52)$ & 0.581 \\
\hline HIT-6 & $\mathrm{N}=27$ & $67.04( \pm 5.68)$ & $\mathrm{N}=27$ & $55.15( \pm 13.69)$ & $<0.001^{*}$ & $\mathrm{~N}=24$ & $68.50( \pm 6.54)$ & $\mathrm{N}=24$ & $66.88( \pm 9.13)$ & 0.343 \\
\hline \multicolumn{11}{|c|}{ Affect Scores } \\
\hline HAD-A & $\mathrm{N}=27$ & $12.19( \pm 4.89)$ & $\mathrm{N}=27$ & $8.04( \pm 4.75)$ & $<0.001^{*}$ & $\mathrm{~N}=24$ & $12.13( \pm 5.23)$ & $\mathrm{N}=24$ & $12.46( \pm 5)$ & 0.786 \\
\hline HAD-D & $\mathrm{N}=27$ & $11.11( \pm 4.93)$ & $\mathrm{N}=27$ & $6.33( \pm 5.53)$ & $<0.001^{*}$ & $\mathrm{~N}=24$ & $13.08( \pm 4.52)$ & $\mathrm{N}=24$ & $12.46( \pm 5) .06$ & 0.452 \\
\hline BDI-II & $\mathrm{N}=27$ & $23.65( \pm 12.76)$ & $\mathrm{N}=27$ & $14.92( \pm 10.84)$ & $<0.001 *$ & $\mathrm{~N}=24$ & $32.04( \pm 15.21)$ & $\mathrm{N}=24$ & $31.74( \pm 16.33)$ & 0.921 \\
\hline \multicolumn{11}{|c|}{ Quality of Life Scores } \\
\hline \multicolumn{11}{|l|}{ Euro-QoL } \\
\hline Euro-QoL & $\mathrm{N}=26$ & $0.75( \pm 0.09)$ & $\mathrm{N}=26$ & $0.75( \pm 0.13)$ & 0.693 & $\mathrm{~N}=22$ & $0.63( \pm 0.10)$ & $\mathrm{N}=22$ & $0.62( \pm 0.13)$ & 0.719 \\
\hline Euro-Scale & $\mathrm{N}=26$ & $61.42( \pm 18.17)$ & $\mathrm{N}=26$ & $68.12( \pm 19.17)$ & 0.106 & $\mathrm{~N}=22$ & $35.95( \pm 21.54)$ & $\mathrm{N}=22$ & $38.86( \pm 24.58)$ & 0.373 \\
\hline \multicolumn{11}{|l|}{ SF-36 } \\
\hline SFP & $\mathrm{N}=27$ & $34.40( \pm 9.48)$ & $\mathrm{N}=27$ & $37.72( \pm 11.66)$ & 0.106 & $\mathrm{~N}=24$ & $29.56( \pm 10.07)$ & $\mathrm{N}=24$ & $29.43( \pm 10.55)$ & 0.932 \\
\hline SFM & $\mathrm{N}=27$ & $36.25( \pm 13.76)$ & $\mathrm{N}=27$ & $44.69( \pm 13.31)$ & $0.008 *$ & $\mathrm{~N}=24$ & $31.64( \pm 13.49)$ & $\mathrm{N}=24$ & $30.95( \pm 13.14)$ & 0.933 \\
\hline
\end{tabular}

BDI-II, Beck Depression Inventory II; HAD-A, Hospital Anxiety and Hospital Depression Scores - Anxiety component; HAD-D, Hospital Anxiety and Hospital Depression Scores - Depression component; HIT-6, Headache Impact Test 6 Score; MIDAS, Migraine Disability Assessment Score; ONS, Occipital Nerve Stimulation; SF-36, short form 36-item health survey. SF-36 subscales: PF, physical function; RP, role 
physical; BP, bodily pain; GH, general health; VT, vitality; SF, social function; RE, role emotional; MH, mental health. SF-36 composite domains: SFP, physical component; SFM, mental component

Supplementary Table 2: Headache disability and quality of life scales by treatment response 


\begin{tabular}{|l|c|c|c|c|c|c|}
\hline \multirow{2}{*}{} & \multicolumn{3}{|c|}{ Responders $(\mathbf{n}=36)$} & \multicolumn{3}{c|}{ Non-responders $(\mathrm{n}=27)$} \\
\cline { 2 - 6 } & Pre-ONS & Post-ONS & P-value & Pre-ONS & Post-ONS & P-value \\
\hline Mean daily attacks $($ SD) & $3.89( \pm 1.98)$ & $0.48( \pm 0.70)$ & $<0.001^{*}$ & $3.54( \pm 1.67)$ & $3.96( \pm 2.03)$ & 0.253 \\
\hline $\begin{array}{l}\text { Mean attack intensity } \\
\text { (SD) [VRS] }\end{array}$ & $8.94( \pm 1.31)$ & $4.63( \pm 4.01)$ & $<0.001^{*}$ & $7.85( \pm 1.74)$ & $7.90( \pm 1.78)$ & 0.858 \\
\hline $\begin{array}{l}\text { Mean attack duration } \\
\text { (SD) [hours] }\end{array}$ & $1.59( \pm 1.06)$ & $0.45( \pm 0.58)$ & $<0.001^{*}$ & $1.74( \pm 2.11)$ & $1.31( \pm 1.14)$ & 0.111 \\
\hline
\end{tabular}

B.

\begin{tabular}{|l|c|c|c|}
\hline & Responder & Non Responder & P Value \\
\hline $\begin{array}{l}\text { Mean final patient estimate } \\
\%\end{array}$ & $78.87( \pm 26.63)$ & $25.63( \pm 29.57)$ & $<0.001 *$ \\
\hline $\begin{array}{l}\text { Maximum patient estimate } \\
\%\end{array}$ & $88.37( \pm 19.61)$ & $40.42( \pm 32.53)$ & $<0.001 *$ \\
\hline
\end{tabular}

C:

\begin{tabular}{|l|c|c|c|c|c|c|}
\hline \multirow{2}{*}{} & \multicolumn{3}{|c|}{ Responders (n=36) } & \multicolumn{3}{c|}{ Non-responders (n=27) } \\
\cline { 2 - 6 } & Pre-ONS & Post-ONS & P-value & Pre-ONS & Post-ONS & \multicolumn{1}{c|}{ P-value } \\
\hline $\begin{array}{l}\text { Mean monthly triptan } \\
\text { dose (SD) } \\
\text { Range }\end{array}$ & $33.78( \pm 28.11)$ & $4.41( \pm 7.69)$ & $<0.001 *$ & $40.25( \pm 36.72)$ & $36.50( \pm 41.73)$ & 0.467 \\
\hline
\end{tabular}




\begin{tabular}{|l|c|c|c|c|c|c|}
\hline $\begin{array}{l}\text { Mean monthly triptan } \\
\text { cost per-patient(SD) } \\
\text { Range (£) }\end{array}$ & $\begin{array}{c}£ 692.44 \\
( \pm 576.20)\end{array}$ & $£ 90.35( \pm 157.69)$ & $<0.001 *$ & $£ 825.13$ & $£ 748.25$ & 0.467 \\
& & & & $( \pm 752.74)$ & $( \pm 855.64)$ \\
\hline
\end{tabular}

ONS, Occipital nerve Stimulation; SD, Standard deviation; VRS, verbal rating scale

Supplementary Table 3: Headache outcome measures (A), patient estimate of improvement (B) and triptan use(C) by response to occipital nerve stimulation 